\title{
A Water-Balance, Climate Model for Range Herbage Production
}

\author{
J. ROSS WIGHT AND R.J. HANKS
}

\begin{abstract}
A crop production model was modified and evaluated for application to native grassland ecosystems. The model effectively predicted annual herbage production for range sites near Sidney, Montana, and Mandan, North Dakota, where model-predicted yields were within $10 \%$ of field measured yields for 12 of the 15 test years. Soil water content, as calculated by the model, was also closely correlated $\left(r^{2}=0.91\right)$ with field measured soil water. Model inputs include beginning soil water content, daily precipitation, and an estimate of potential evapotranspiration. Soil water content, evaporation, and transpiration are calculated daily. Yields are determined as a function of the actual to potential transpiration ratio. Availability of input data, relative simplicity, and low computer costs make this model a viable tool for both research and resource management.
\end{abstract}

Past attempts to predict range herbage production have relied primarily on statistical relationships between plant growth and precipitation and soil water. The work of Rogler and Haas (1947), Sneva and Hyder (1962), Currie and Peterson (1966), and Shiflet and Dietz (1974) are examples. Additional climatic variables, such as pan evaporation, wind, temperature, and solar radiation measurements, have also been included in yield predicting multiple regression equations (Smoliak 1956; Johnston et al. 1969). In these studies, growing-season precipitation and fall or spring soil water content accounted for most of the variation in yield. Lack of transferability of these statistical models to other sites, and often to other data sets from the same site, have limited their use.

In recent years, some water-balance, climate models, as reported by Aase et al. (1973), de Jong and MacDonald (1975), Hanson (1976), and Ritchie et al. (1976), have been developed to predict evapotranspiration (ET) from native rangelands. However, the use of water-balance, climate models to predict range forage produc-

\footnotetext{
Authors are range scientist, U.S. Dep. Agr., Sci. and Educ. Admin., Agr. Res., Northwest Watershed Research Center, 1175 South Orchard-Suite 116, Boise, Idaho 83705, (formerly at Northern Plains Soil and Water Research Center, Sidney, Montana); and professor, Department Soil Science and Biometeorology, Utah State University, Logan, respectively.

This report is a contribution from U.S. Dep. Agr. Sci. and Educ. Admin., Agr. Res., and Utah State University, Logan.

Manuscript received December 12, 1979.
}

tion has not received much attention, although the potential has been recognized. Aase et al. (1973) suggested that model-predicted soil water would be useful for forecasting forage yields. In Canada, de Jong and MacDonald (1975) reported a high correlation ( $r=$ 0.99 ) between ET (water-use) and annual range herbage yields.

The grassland simulation model ELM (Innis 1978) was a major output of the United States International Biological Program, Grassland Biome Study, and the model, or one of its more recent versions, is probably the most comprehensive current rangeland ecosystem model. Biomass simulation is only one component of the model, and it is calculated by monitoring the flow of carbon through several groups of species and several plant phenophases. A water-balance, climate submodel is used to drive the plant growth and other model components. The model was developed primarily as a research tool for the shortgrass biome study, and has had some application to problems of management and research in other grassland ecosystems and in disturbed land reclamation.

Incrcasingly, there have been efforts to quantify the physical aspects of crop production. These "physical models" are more transferable between sites, years, and crops than are the statistical models. Also, development of physical models provides considerable information relative to basic plant growth-environment relationships.

Hanks (1974) and Rasmussen and Hanks (1978) described a water-balance, climate model that is relatively simple in terms of input parameters and computations and that has effectively predicted dry matter production for cultivated crops such as wheat. The purpose of this study was to determine the applicability of such a model to a rangeland ecosystem.

\section{Description of Model}

The water-balance, climate model used in this study is essentially the same as that described by Hanks (1974) and Rasmussen and Hanks (1978) without the irrigation, phenology, and grain yield components. The major modifications were in the soil water extraction and root growth components. The transpiration and evaporation factors were modified to reflect the perenniality and cover characteristics of native vegetation as compared with those 
for annual crops, for which the model was originally developed.

The basic assumption of the model is described by the equation:

$$
\frac{Y}{Y_{p}}=\frac{T}{T_{p}}
$$

where $\mathrm{Y}=$ actual yield

$Y_{p}=$ potential yield (yield with water nonlimiting)

$\mathrm{T}=$ actual transpiration

$T_{p}=$ potential transpiration

Calculation of $T$ and $T_{p}$ are as follows:

$$
T_{p}=b K_{c} E_{o}
$$

$$
\mathrm{T}=\mathrm{T}_{\mathrm{p}} \frac{(\mathrm{SWS} / \mathrm{AW})}{c} \text { if } \mathrm{SWS} / \mathrm{AW} \leq \mathrm{c}
$$

or

where

$$
\mathrm{T}=\mathrm{T}_{\mathrm{p}} \text { if SWS } / \mathrm{AW}>\mathrm{c}
$$

$E_{0}=$ evaporation from a free water surface (estimated from pan evaporation or calculated by methods such as that of Jensen-Haise (1963)

$\mathbf{K}_{c}=$ crop coefficient

SWS = existing available soil water

AW $=$ available soil water storage capacity

$\mathrm{b}=0.5 \mathrm{x}$ relative area index (LAI)

$c=$ the SWS $/ A W$ value at which becomes a linear function of SWS/AW

In converting $T / T_{p}$ to $Y$, a good estimate of $Y_{p}$ for the site and conditions to which the model is being applied is needed. The $Y_{p}$ of a specific site or area is the maximum yield that would occur if water were nonlimiting and includes the effects of such yieldregulating variables as species composition and soil fertility that arc associated with the site or area.

As the model operates, water is added to the soil by precipitation and removed by soil evaporation, $\mathrm{T}$, and drainage. The soil profile is divided into appropriate layers and water is added or subtracted from one soil layer at a time. If, following a rain, the water content of the surface layer exceeds field capacity, water is added to the next layer and so until all precipitation is accounted for or until all soil layers are filled. Excess water is counted as drainage. In this study, three $30-\mathrm{cm}$ soil profile layers were used so that modelpredicted soil water values could be compared with field-measured values that had been determined at 30-cm depth increments. Soil layers may be more appropriately assigned on the basis of soil horizons or root distribution characteristics where data are available.

Soil water extraction also proceeds one layer at a time beginning at the surface layer. If the surface soil layer cannot, under the imposed constraints, supply enough water to meet daily $T_{p}$, the model then extracts water from the second layer and so on, until $T_{p}$ has been satisfied or until all layers have been sampled. If $T_{p}$ cannot be satisfied from soil layer $i$, then full $T_{p}$ demand is applied to soil layer $i+1$ but extraction cannot exceed the difference between $T_{p}$ and $\mathrm{T}$ from the preceding soil layers.

Actual soil evaporation $(E)$ is a function of potential soil evaporation $\left(E_{p}\right)$ and time since the soil surface was last wet and is calculated as follows:

$$
\mathrm{E}=\mathrm{E}_{\mathrm{p}} / \mathrm{t}^{1 / 2}
$$

where $\mathrm{t}=$ time in days since the last wetting of the soil surface and

$$
E_{p}=K_{c} E_{o}-T_{p}
$$

Soil evaporation is limited to the amount of water in the surface soil layer in excess of the air-dry soil water content, which is slightly less than the lower limits of soil water availability (permanent wilting point).

In addition to the climatic parameters and water-holding characteristics, soil water extraction is further controlled by a root activity factor that is a function of soil temperature (Fig. 1)

This method of soil water extraction represents a significant change from that of Hank's (1974) original model, which was designed for annual crops and provided a root growth function to

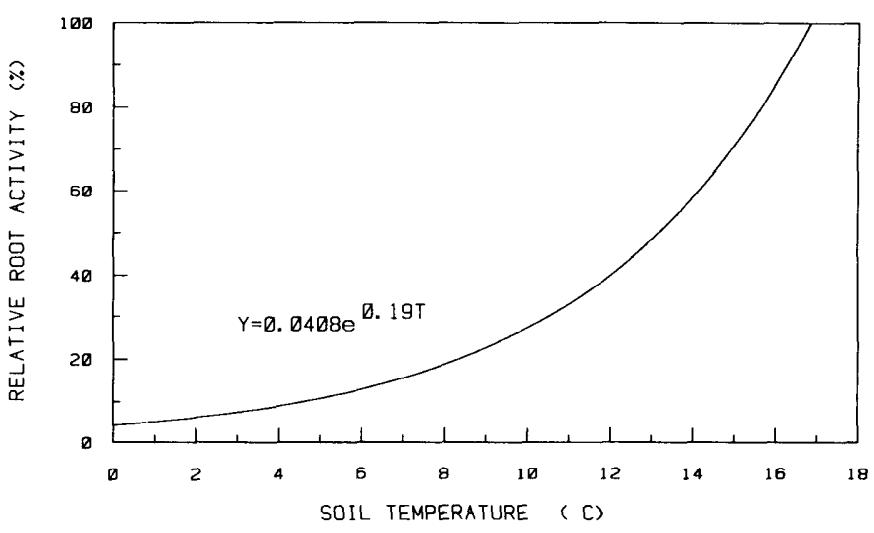

Fig. 1. Relationship between relative root activity and soil temperature (approximated from data of de Jong 1974).

represent the cxtension of roots into the various soil profile layers. Once roots reached a soil layer, water was extracted from the soil layer that contained the most available water. When this model was applied to the perennial native vegetation of our study site excessive amounts of water were extracted from the second and third layers of soil.

The model proceeds on a day-to-day basis calculating $T_{p}, T, E_{p}$, $E$ and keeps a running account of $T, T_{p}$, and $S W S$ for each soil layer. In this study, the model runs were terminated to coincide with field harvest dates, and only total annual herbage yields were predicted.

Model inputs include the available soil water holding capacity (AW) of each soil layers; the air-dry water content of the surface layer, the available soil water content (SWS) of each layer at the beginning of the growing season, daily precipitation, and daily or periodic estimates of $E_{0}$. Using average $E_{o}$ values for up to 10-day periods has proved satisfactory. In this study, we assumed there was no runoff.

\section{Model Calibration}

As used in this paper, the model has no coefficients that are used strictly for calibration. However, we had to do some "fitting" of the factors that relate $T_{p}$ to $E_{o}$ and T to SWS. Usually these factors were calculated from existing data at the Sidney study site or estimated from the literature. When necessary, fitting was done through trial and error, using a below average, average, and above average production year. The $K_{c}$ was estimated by plotting $E T / E_{0}$, where evapotranspiration (ET) was determined weekly from a hydraulic lysimeter, during periods when soil water was at or near nonlimiting levels, and $\mathrm{E}_{\mathrm{o}}$ was calculated from daily maximum and minimum air temperatures and solar radiation (Jensen and Haise 1963). The lysimeter was cropped with native range and was located adjacent to the Sidney study site. Although $\mathrm{Et} / \mathrm{E}_{\mathrm{o}}$ tended to range from 0.7 in the spring and fall to 0.9 during midgrowing season, 0.85 represented a growing season average and resulted in yield and soil water estimates that were as good when a seasonal $\mathbf{K}_{\mathbf{c}}$ curve was used.

A relative LAI curve, developed from the data of Hanson (1973), was used to represent seasonal changes in $T_{p} / K_{c} E_{o}$ (Fig. 2).

There have been considerable controversy and discussion over the relationship between $T / T_{p}$ and soil water availability. Hanks (1974) reviewed several of these relationships and concluded that for his work the combination method (equation 3) was best. For wheat, Rasmussen and Hanks (1978) used a $c$-value of 0.5. A $c$-value of 0.7 for native range was reported by de Jong and MacDonald (1975). We started with the combination method and tried several values of $c$. The model was not sensitive to small changes in $c$, and, thcrcforc, cxact knowledge of this relationship is not critical. In this study, a straight linear relationship $(c=1.0)$ was effective for both soil water and yield prediction, and thus equation (4) was never invoked. 


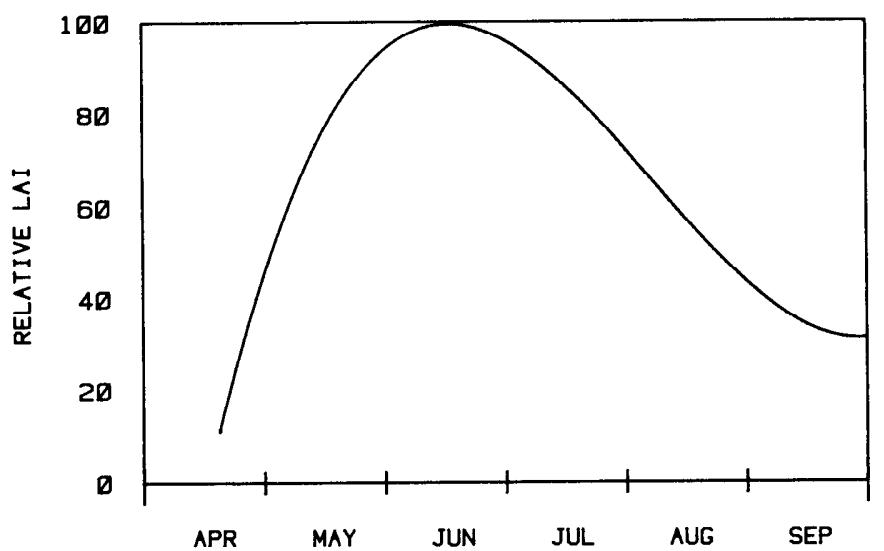

Fig. 2. Seasonal changes in relative LAI. (Calculated from data of Hanson 1973).

For the second and third soil layers, additional temperature dependent root-activity constraints were imposed (Figs. I and 3 ). In northern climates, soil temperature significantly affects root activity and subsequent soil water extraction, and such an effect was evident in the soil water extraction patterns in this study. Water extraction from the second and third $30-\mathrm{cm}$ soil layers was restricted by calculated root activities (Fig. 1). Approximate soil temperature curves, as reported by de Jong (1978), for Swift Current, Saskatchewan, Canada, were used to calculate seasonal root activities (Fig. 3). We assumed that soil temperature did not significantly restrict $\mathrm{T}$ of the surface soil layer water.

For the Sidney site, $Y_{p}$ was estimated from herbage yield data to be about $1,300 \mathrm{~kg} / \mathrm{ha}$. Yields seemed to peak at this value, regardless of the amount of precipitation (Wight and Black 1979). The $Y_{p}$ for Mandan was also determined from yield data and was estimated to be about $2,760 \mathrm{~kg} / \mathrm{ha}$. The $Y_{p}$ for a given site could also be estimated by the relationship $\mathrm{Y}_{\mathrm{p}}=\mathrm{YT}_{\mathrm{p}} / \mathrm{T}$ calculated for representative years.

Establishment of a starting date for each growing season presented a problem that was somewhat different from that of an annual crop. Growth of cool-season grasses, like western wheatgrass (Agropyron smithii), begins as soon as air and soil temperatures are above freezing. However, periodic low freezing temperatures, following initial growth, can remove existing growth and a new starting date is required. In this study, we ran the model using the last day the minimum air temperature dropped to $-7^{\circ} \mathrm{C}$ as a starting date. We also made runs using April 1, April 15, and May 1 as a general starting date for all years. Because very little net growth occurred during April, small changes in starting date did not have a significantly large effect. The temperature dependent

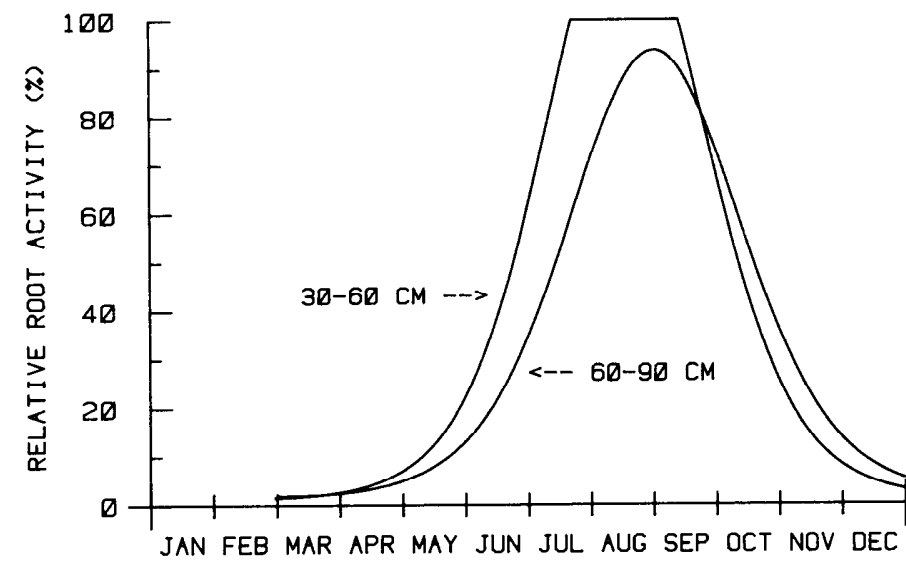

Fig. 3. Seasonal changes in root activities for the 30- to 60-cm and 60- to 90-cm soil layers. starting date and April 15 were about equally effective and produced predicted yields that were a little more closely correlated with field measured yields than did the April 1 and May 1 starting dates. In this study, we used April 15 for the Sidney data and the temperature dependent starting date for the Mandan data.

\section{Field Data}

Herbage yields and climatological data from mixed prairie range sites near Sidney, Montana and, Mandan, North Dakota, were used to modify and evaluate the production model. The Sidney site has been described by Wight and Black (1979) as a sandy, glaciated plains range site. Total herbage yields were determined when the major grass species reached maturity - about peak standing crop. Yiclds were measured by clipping several $0.5-$ by $2.0-\mathrm{m}$ sample quadrats at ground level. Daily precipitation was measured at the site, and solar radiation and maximum and minimum air temperatures were recorded at a nearby weather station. Water-holding capacity and permanent wilting point of the three $30-\mathrm{cm}$ soil layers and the air-dry water content of the surface layer $(0-30 \mathrm{~cm})$ were determined from field data and pressure plate desorption curves.

The Mandan data were obtained from a study reported by Lorenz (1970). Field capacity, permanent wilting, and air-dry water content of the surface layer were estimated from data reported by Cole and Mathews (1939). Daily precipitation and maximum and minimum air temperatures were obtained from a weather station located within $1 \mathrm{~km}$ of the study site. Solar radiation was obtained from the Bismarck, North Dakota, weather station located about $15 \mathrm{~km}$ east of the study site.

In this study, $\mathrm{E}_{0}$ was calculated by the Jensen-Haise Method (Jensen and Haise 1963), and $K_{c}$ was assumed constant at 0.85 for the entire growing season. At the Sidney site, daily calculated $\mathrm{E}_{0}$ was used as the model input, whereas average daily $E_{o}$ for 7-day periods was used for the Mandan data.

At the Sidney site, soil water was determined biweekly throughout the growing season by the neutron method at the study area weather station.

\section{Results and Discussion}

The model produced reasonable estimates of herbage production on the Sidney range site for the 1967-1978 test period (Table 1 and Fig. 4). The $r^{2}$ value of 0.74 was calculated from the least squares fit of the data points to the line of equal value. For most years, predicted yields were within the sampling error of the field-

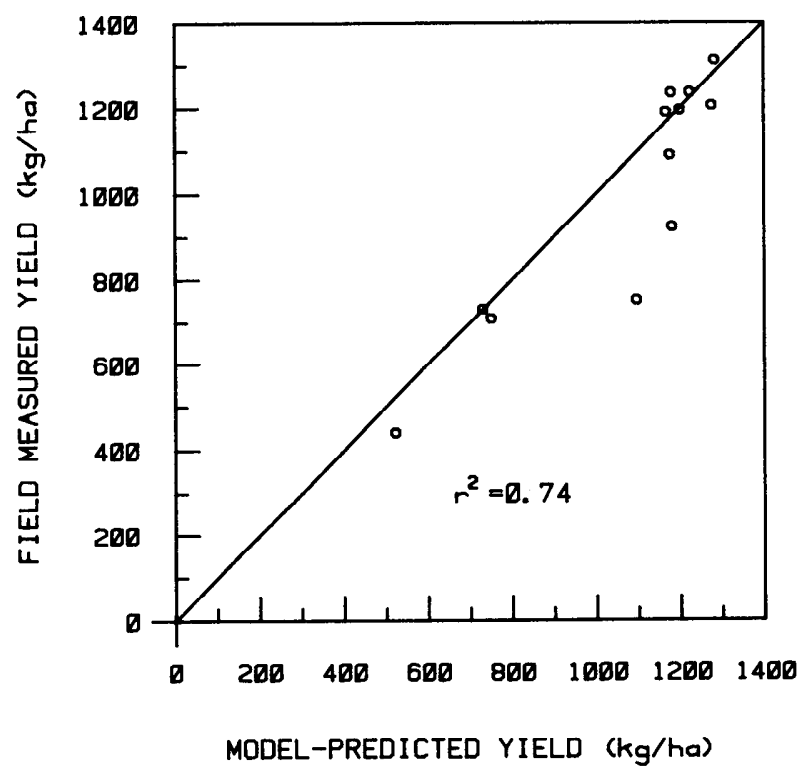

Fig. 4. Relationship between field-measured and model-predicted herbage yields for 1967-1978. Sidney, Montana. 
Table 1. Crop coefficient $(\mathrm{Kc}) \times$ free-water evaporation (Eo), potential transpiration (Tp), actual transpiration (T), evapotranspiration (ET), drainage, yield, precipitation (pptn), and growth period for 1976-1978. Sidney, Montana.

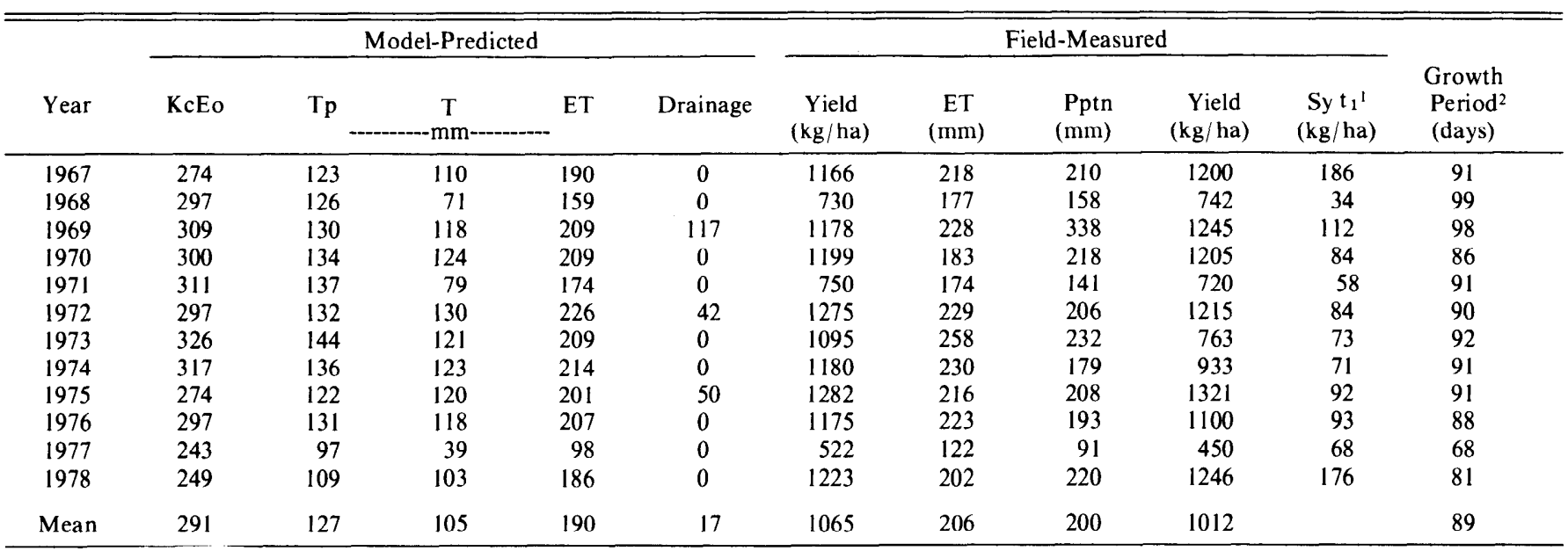

IPlus or minus $\mathrm{S}_{\mathrm{y}} \mathrm{t}_{1}$ is the $90 \%$ confidence interval of the field-measured yield mean.

${ }_{2}$ Measured from April 15 to peak standing crop.

measured yields (Table 1). Deviations between field- and modelpredicted yields were greatest in 1973 and 1974, which had high evaporative demands and drought periods during April and/or May followed by favorable soil water during most of June and July. These drought periods appeared to have had a disproportional effect on the total plant growth. In its current form, the model has no mechanism to account for the effects of drought during various growth periods on subsequent plant growth. In a mixed prairie plant community, where many species contribute to the total production, periods of stress have a differential effect on the growth and development of the various species. For example,

1967

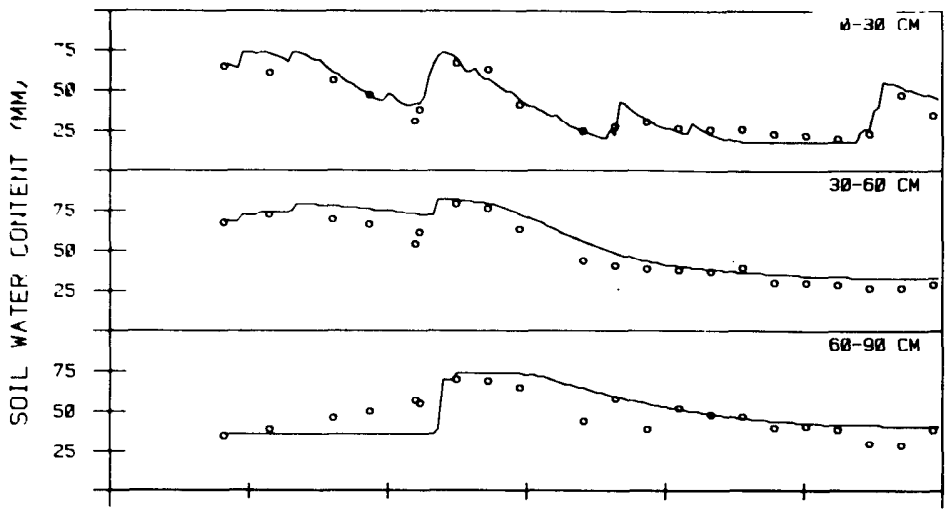

1969

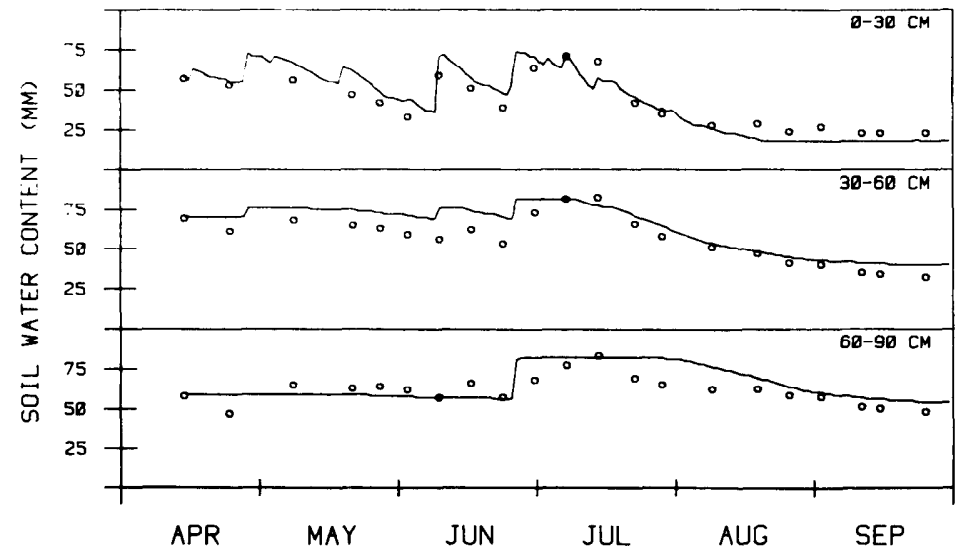

threadleaf sedge (Carex filifolia) usually sets seed and terminates annual growth at the onset of an early drought period, whereas western wheatgrass becomes dormant and resumes growth when water again becomes available.

Using data from Mandan, the model effectively predicted peak standing crop. Accuracy of predicted yields was similar to that obtained at Sidney. For 1958, 1959, and 1960, the model predicted yields of $1,930,1,128$, and $2,245 \mathrm{~kg} / \mathrm{ha}$, respectively, as compared with field-measured yields of $1,767,1,405$, and $2,105 \mathrm{~kg} / \mathrm{ha}$, respectively.

A significant feature of the model is its ability to predict seasonal 1968

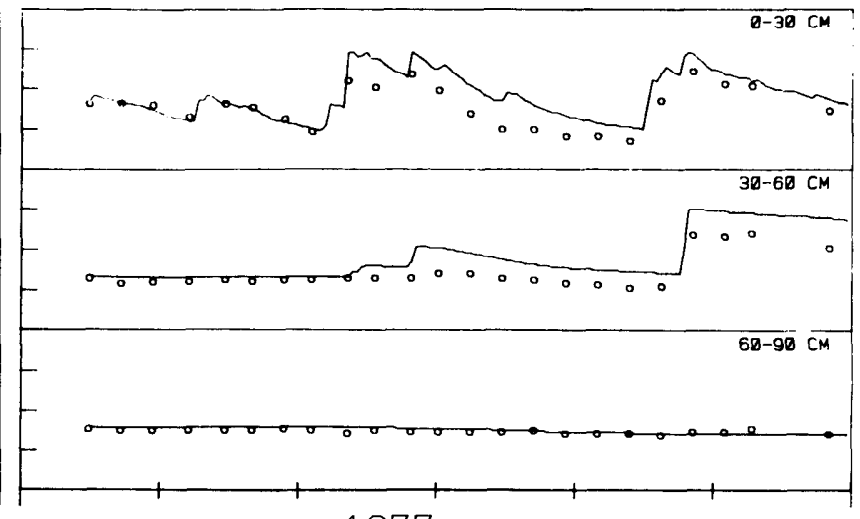

1977

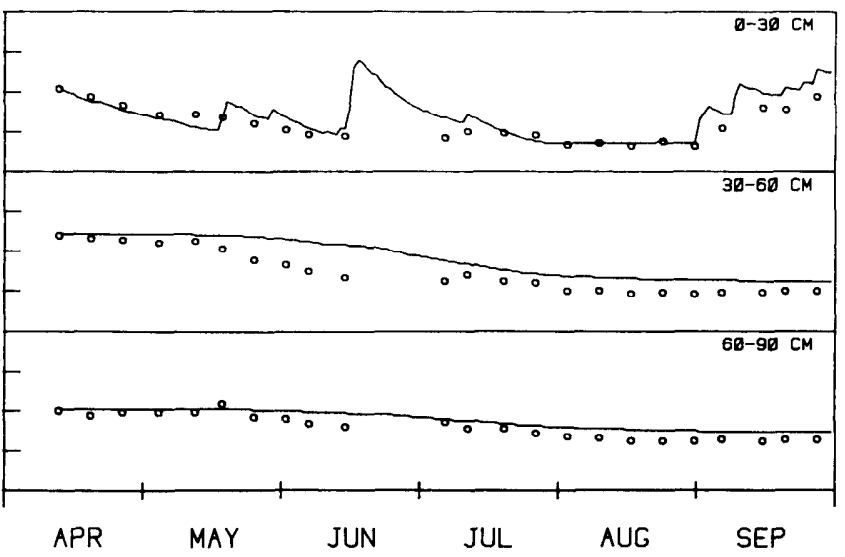

Fig. 5. Field-measured and model-predicted soil water content (cm water/30-cm soil increment). Sidney, Montana. 
changes in soil-water content (Fig. 5). Agreement between fieldmeasured and model-predicted values was good for all soil layers. Average model-predicted ET was slightly less than field measured ET (Table 1). These ET values are for April 15 to peak standing crop, and thus the small difference between model-predicted ET and field measured ET may indicate that the model is overly restrictive of water uptake during the early portion of the growing season.

A generalized LAI curve (Fig. 2) worked well for determining $T_{p} / K_{c} E_{o}$. However, a similar curve should be developed that is representative of the region where the model is used. Further improvement of the model could be obtained through use of a temperature-dependent function that would shift the LAl curve to reflect yearly climatic variations.

Although the general soil temperature curves used in this study worked well, a logical refinement would be to utilize a soil temperature submodel, such as that described by Hanks et al. (1971). Such a refinement would make the model more sensitive to yearly growing conditions and would enhance the modeling of seasonal growth. During spring of 1977 , for example, the model underpredicted water extraction from the $30-$ to $60-\mathrm{cm}$ soil layer (Fig. 5). Weather station records showed that average April and May air temperatures in 1977 were significantly higher than those during other study years. These unseasonably warm air temperatures, coupled with a dry soil, undoubtedly resulted in much warmer soil temperatures and higher root activities earlier in the growing season than that indicated by the general soil temperature curve.

The transferability of this "crop" model to a native grassland ecosystem supports the integrity of its basic algorithms and indicates that it could be transferable to other ecosystems with appropriate changes in input parameters. The model's relative simplicity and availablity also help make it a viable tool in plant-environment research and rangeland management.

\section{Literature Cited}

Aase, J.K., J.R. Wight, and F.H. Siddoway. 1973. Estimating soil water content on native rangeland. Agr. Meteorol. 12:185-191.

Cole, John S., and O.R. Mathews. 1939. Subsoil moisture under semiarid conditions. U.S. Dep. Agr. Tech. Bull. 637.

Currie, Pat O., and Geraldine Peterson. 1966. Using growing season precipitation to predict crested wheatgrass yields. J. Range Manage. 19:284288 . de Jong, E. 1974. Modelling. VII. Soil water simulation models. Tech. Rep. No. 61 IBP, Matador Project.

de Jong, E., and K.B. MacDonald. 1975. The soil moisture regime under native grassland. Geoderma 14:207-221.

de Jong, R. 1978. Energy and the Forage Crop. p. 24-40. In: J.D. McElgunn, (Ed.) Pasture Systems for the Cow-Calf. Agr. Can. Res. Ta. Swift Current, Saskatchewan, Canada.

Hanks, R.J., D.D. Austin, and W.T. Ondrechen. 1971. Soil temperature estimation by a numerical method. Soil Sci. Soc. Proc. 35:665-667.

Hanks, R.J. 1974. Model for predicting plant yield as influenced by water use. Agron. J. 66:660-665.

Hanson, Clayton L. 1973. Model for predicting evapotranspiration from native rangelands in the northern Great Plains. Ph.D. Thesis. Utah State Univ., Logan. 116 p.

Hanson, Clayton, L. 1976. Model for predicting evapotranspiration from native rangelands in the northern Great Plains. Trans. ASAE 19:471477,481 .

Innis, George S. (Ed.) 1978. Grassland Simulation Model. Ecological Studies 26, p. 1-298. Springer-Verlag, New York.

Jensen, M.E., and H.R. Haise. 1963. Estimating evapotranspiration from solar radiation. Amer. Soc. Civil Eng. Proc., J. Irrig. and Drain. Div. 89:15-41.

Johnston, A., S. Smoliak, A.D. Smith, and L.E. Lutwick. 1969. Seasonal precipitation, evaporation, soil moisture, and yield of fertilized range vegetation. Can. J. Plant Sci. 49:123-128.

Lorenz, Russell James. 1970. Response of mixed prairie vegetation to fertilization and harvest frequency. Ph.D. Thesis, North Dakota State Univ., Fargo, North Dakota. 135 p.

Rasmussen, V.P., and R.J. Hanks. 1978. Spring wheat yield model for limited moisture conditions. Agron. J. 70:940-944.

Ritchie, J.T., E.D. Rhoades, C.W. Richardson. 1976. Calculating evaporation from native grassland watersheds. Trans. ASAE 19(6): 1098-1103.

Rogler, George A., and Howard J. Haas. 1947. Range production as related to soil moisture and precipitation on the northern Great Plains. J. Amer. Soc. Agron. 39:378-389.

Shiflet, Thomas N., and Harland E. Dietz. 1974. Relationship between precipitation and annual rangeland herbage production in southeastern Kansas. J. Range Manage. 27:272-276.

Smoliak, S. 1956. Influence of climatic conditions on forage production of shortgrass rangeland. J. Range Manage. 9:89-91.

Sneva, Forrest A., and D.N. Hyder. 1962. Estimating herbage production on semiarid ranges in the intermountain region. $J$. Range Manage. 15:88-93.

Wight, J. Ross, and A.L. Black. 1979. Range fertilization: Plant response and water use. J. Range Manage. 32:345-349.

\section{Available through SRM \\ Constraints to Improved Management of Public Rangelands}

Edited by Paul E. Packer and James O. Klemmedson, this SAF publication includes papers of a panel discussion presented by Range Ecology Working Group of the Society of American Foresters, Spokane, Washington, October 7, 1980. Topics and speakers are:

Introductory Remarks: Thadis W. Box, Moderator

Physical-Biological Constraints to Improved Management of Public Rangelands: E. Lamar Smith

Economic Incentives and Range Improvements on Federal Rangelands: E. Bruce Godfrey and Darwin B. Nielsen

Constraints or Challenges? Social Dilemmas in Public Rangeland Management: Patrick C. West

Range Management in the 1980's; a Brief Look at the Political Context: Sally K. Fairfax

Legal Constraints on Public Rangeland Management: Gail L. Achterman.

Copies are available for $\$ 1.00$ each from the Society for Range Management, 2760 West Fifth Avenue, Denver, CO 80204. 